\title{
Development of the Concept and Implementation of National Forest Programs with Reference to Croatia
}

Marko Lovrić

Croatian Forest Research Institute

Vilka Novaka 50c

42000 Varaždin

Croatia

markol@sumins.hr

\author{
Nataša Lovrić \\ Croatian Forest \\ Research Institute \\ Vilka Novaka $50 \mathrm{c}$ \\ 42000 Varaždin \\ Croatia
}

Dijana Vuletić

Croatian Forest

Research Institute Cvjetno naselje 41

10450 Jastrebarsko

Croatia

\author{
Ivan Martinić \\ Faculty of Forestry, \\ University of Zagreb \\ Svetošimunska 25 \\ 10000 Zagreb \\ Croatia
}

\section{Abstract}

Background and purpose: National forest programs have been promoted by the international forest policy sphere as a preferred form of policy process by which the sustainable forest management should be reached on national level. As such, it has received a lot of attention in the international legislation and has been important part of the forest policy dialogue. This paper examines the national forest programs from the side of its theoretical development, and how it has been transposed from the international sphere onto the national domains.

Materials and methods: Paper examines international legislation refereeing to the national forest programs, and provides an overview of its development. Comparative analysis of national forest program processes in Europe has been made, along with presentation of different national approaches to it. Topic-related scientific literature has been analyzed, with special emphasis on its procedural elements.

Results and conclusions: International legislation shows great coherence regarding the development of the concept of national forest programs. The same coherence is present in the scientific community, but not among the forest policy practitioners, which is reflected by a great variety of developments of national forest programs across Europe. This variety is not as important as are the procedural aspects of the process, which promote mode of governance in line with the new general paradigm of forest planning. The article critically reviews the procedural and outcome elements of national forest programmes, which are then analysed in the context of Croatian perspectives for a formal process of a national forest program.

Keywords: National forest program, participation, power relations

\section{INTRODUCTION}

National Forest Program (NFP) does not have a clear-cut definition, for it is a "generic expression for a wide-range of approaches towards forest policy formulation, planning and implementation at the subnational and national levels" [1]. In a broader understanding it is not even a document, but an iterative process of goal setting, policy planning and implementation within a wide participatory context [2-4]. This is also in line with the position of the Ministerial Conferences on the Protection of Forests in Europe (MCPFE), which defines NFP as a "...participatory, holistic, inter-sectoral and iterative process of policy planning, implementation, monitoring and evaluation at the national and/or sub-national level in order to proceed towards the further improvement of sustainable forest management..." [5]. More narrow definition of it, stemming from the review of NFP documents in Europe, would state that NFP is a mid-term strategic planning document of (usually) ten year validity in which actions set by the long-term Strategy are disseminated through a participatory process into concrete indicators, which have its financial resources, deadlines, implementing agencies and verifications of completion.

The goal of NFP process is country-driven forest sector development, in which the implementation of international forest-related obligations is embedded in. Although the country-leadership is one of the basic principles of NFP, there is a wide range of global initiatives to support its development [4]. In this context NFP is a policy process, and in which there are outputs to each phase of its policy cycle (analysis, formulation, implementation, monitoring and evaluation). The aim 
of the paper is to review the scientific literature on the NFP, its national implementation in selected countries and to critically review its procedural and outcome characteristics. These findings are then commented in the context of Croatian perspectives on a formal NFP process.

\section{MATERIAL AND METHODS}

International legislation that has references to NFPs has been analyzed on global, pan-European, EU and Croatian level. Analysis shows the development of the concept on different levels and the similarities between the approaches.

The data base of the United Nations Economic Commission for Europe (UNECE) of reports on the panEuropean Qualitative indicators for sustainable forest management and national implementation of commitments of the Ministerial Conference on the Protection of Forests in Europe has been analyzed. Elements of the analysis were: relation of the strategic documents to a formal NFP process; inclusion of stakeholders in the policy formulation; balance of economic, social and environmental sides of the sustainability in the policy; uptake of MCPFE instruments. A comparative analysis of development of the NFP processes in 32 European countries has been made. The NFP documents referenced in the UNECE's data base have been analyzed, and a short overview of examples of different development paths of the national NFP processes has been presented, i.e. the cases of Kirgizstan, Finland, Switzerland, Slovenia, Serbia, and the Federation of Bosnia and Herzegovina, Bosnia and Herzegovina.

Scientific literature on NFP has been analyzed, and emphasis has been given on the definition, principles and rationale of the NFP. Critical discussion on the concepts related to procedural elements of the NFP has been made, notably the participation, legitimacy and power. Article ends with a series of recommendation for improving the formulation of NFP documents, with special reference to Croatia.

\section{On the concept of NFP}

There is broad common understanding on what the principles of a NFP are, both on the global [1] and on the European [5] level. The presence of these elements in national forest policy is what defines an NFP, and summed up, these principles are [6]:

- Public participation is the key to the coordination of participants who seek to use forests for their specific interests.

- Holistic and intersectoral co-ordination should ensure that those sectors affecting, and those affected by forest management have an input to the policy process.
- Decentralization refers to the co-ordination of actors operating at different levels.

- Long term, iterative and adaptive planning takes account of failure to achieve goals, as well as of the changing environment and allows for flexibility and adjustment in NFPs.

Along with the principles of NFP, there is also an understanding on what the goal of NFP is, and it can be defined as "... to promote the conservation and sustainable use of forest resources to meet local, national and global needs, through fostering national and international partnerships to manage, protect and restore forest resources and land, for the benefit of present and future generations" [7].

However, in the international processes referring to NFP (IPF/IFF/UNFF and MCPFE) there is no mention on the reasons why the "principles of NFP" should be used in order to reach vague goals as defined by FAO. This lack of explanation makes NFP and its theoretical foundation a normative and politically defined concept [3]. The abstract and imprecise nature of goals and principles of NFPs is the reason why there is no general understanding on the role and the specific content of NFP among the forest policy practitioners in Serbia [8], Germany and Bulgaria [9], or even across Europe [10]. However, this is not the case with the scientific community. Although it is not possible to draw a causal relation to the NFP, there is nonetheless a direct complementary link [11] to the new general paradigm of forest planning [12], in which policy process is characterized by a bargaining system with participation of all relevant actors that strive for a consensual solution within an iterative, fragmented planning process. These are the characteristics of policy process through which international forest policy sphere is trying to incorporate itself onto the national forest policy sphere. The strong international focus in NFP process may be caused by many reasons. Aside from the reason of increasing the rationality of management of forests resources, other reason could be expansion of influence of international organizations onto the national forest policy domain, which should be viewed in the context of failure to produce so far an internationally binding document on forests. And yet another reason could be the inclusion of interests of environmentalists groups onto the national forest policy formulation [13].

Whatever the underlying causes for NFPs are, it can be stated that theoretically the essence of NFP is about policy change in usually hierarchical governmental organizations, which consists out of redefining roles and responsibilities of institutional actors, changing the relationships between stakeholders and transforming the public forestry sector organizations. 
This new mode of governance that NFPs promote can be seen as an informal network of public and private actors which co-operatively strive for the realization of a common benefit - the sustainable forest management [6]. It is important to recognize that by following "principles of NFPs", the policy formulation process in fact produces new knowledge and brings about new capacities, thus incorporating goal setting into the process, and making the process itself as the central component, and not the agreed upon document. On a more theoretical level it can be stated that the NFP process has moved away from the "classical policy planning (implementing public goals through state administration based on rational choice among alternatives [14]) and onto the concepts of communicative action [15] and deliberative democracy [16, 17]. This trend is also present in the forest policy science itself, as the "old" idioms (interest groups, power, public administration) and theories (positivism) have been replaced by new idioms (governance, policy discourses) and theories (neo-institutionalism, discourse theory $[18,19])$. In this context the NFP process should not be based on formal bureaucratic organization, but on a collaborative model of organization with coordinative, directive and team elements, whose general structure is constant, but the members and the content of its elements vary over time [20]. The most important prerequisite for such structure are strong participatory mechanisms.

\section{International legislative framework of NFPs}

The origins of the NFP process can be found in Tropical Forestry Action Program (TFAP), which was an international response to the growing awareness on deforestation. The TFAP was promoted by the Food and Agriculture Organization of the United Nations (FAO) and the World Resources Institute (WRI), which were supported by the World Bank (WB) and the United Nations Development Program (UNDP). The TFAP were a technocratic planning tool, implemented by external staff, and focused mainly on the forestry sector and its' financial support [26]. This lineage can be seen as in 1999 FAO had defined NFP as an instrument for coordinating external assistance for a implementation of a strategic forestry documents on a national level [8], and seven years later [4] has moved to the broad definition from the beginning of this text. It can be stated that generally TFAP failed, due to the restricted point of view, limited agenda, fading sense of national ownership and donor-dependency [4].

At the United Nations Conference on Environment and Development (UNCED) in 1992, within the Chapter 11 of the Agenda 21, a commitment to the development and implementation of "national forestry action programs and/or plans for the management, conservation and sustainable development of forests" was formulated. Same commitment was further on developed by the Intergovernmental Panel on Forests (IPF), The Intergovernmental Forum on Forests (IFF), the United Nations Forum on Forests (UNFF; all succeeding one another) and the Commission for Sustainable Development's (CSD) first working group for forests. The basic message was that NFPs should be a national framework for the implementation of forest-related commitments stemming out of UNCED [13]. The most comprehensive product of these efforts is the 270 IPF/IFF Proposals for action [27] that were produced between the years 1995 and 2000 . The implementation of (150) IPF Proposals for action through NFPs can be clustered into the following groups, which appropriately depict the basic pillars of NFP process [28]:

1. Develop and implement a holistic national forest program which integrates the conservation and sustainable use of forest resources and benefits in a way that is consistent with national, sub-national and local policies and strategies - measures 17a, 70a, 77f and 146e;

2. Develop and implement national policy goals and strategies for addressing deforestation and forest degradation in a participatory manner - measures 29a and 29b;

3. Improve cooperation and coordination systems in support of sustainable forest management within national forest programs which involve all stakeholders including indigenous people, forest owners and local communities in forest decision making - measures 17b, 17f, 17h, 40e and 77f;

4.Develop and apply criteria for effectiveness and adequacy of forest programs - measures $58 \mathrm{~d}$ and $71 b$;

5. Monitor and evaluate implementation progress of a national forest program including the use of criteria and indicators for sustainable forest management - measures $17 \mathrm{a}, 17 \mathrm{~d}$ and $71 \mathrm{~b}$;

6. Develop and promote the concept and practice of partnership, including partnership agreements, between all actors in the implementation of national forest programs - measures $17 \mathrm{a}, 17 \mathrm{i}, 40 \mathrm{~g}$, 40n, 46e and 77c.

Further call for implementation of the IPF/IFF Proposals for action was made in the Non-legally Binding Instrument on All Types of Forests [29]. The same document also states that NFPs should be integrated with instruments of sustainable development and poverty reduction.

The importance of NFPs is also recognized within Forests Europe (formerly known as the MCPFE) policy process. The first mention of NFP in MCPFE process is in 
the Resolution H3 [30], in which the members of the European Community commit themselves to assist countries with economies in transition to develop their NFPs. Five years later in the Resolution L2 [31] the PanEuropean (quantitative) Criteria and Indicators for Sustainable Forest Management (C\&I for SFM [32]) were endorsed as a reference framework for the formulation of NFPs. The NFP was gaining momentum in the MCPFE process, as it was recognized as the first qualitative indicator in the Improved Pan-European Criteria and indicators for Sustainable Forest Management [33]. At the fourth MCPFE held in 2003 in Vienna NFP was the central topic, as in the Vienna Living Forest Summit Declaration [34] NFP was endorsed as a means for inter-sectoral cooperation. The signatory parties of the Resolution V1 [5] commit themselves to use the MCPFE Approach to NFPs, which is annexed to the Resolution. Other resolutions of the Vienna MCPFE in the same context endorse NFPs as method of implementation of different segments of sustainable forest management (Resolution V3 for social and cultural dimensions of SFM, Resolution V4 for biological diversity and Resolution V5 for implementation of obligations stemming from the UNFCCC). Similar mode of endorsement of NFP was present also in the fifth MCPFE held in Warsaw in 2007, where in the Warsaw Declaration [35] signatory states commit themselves to promotion of NFPs, and in the Resolution W2 [36] commit to coordination of forest and water resources through NFPs and integrated water resources management plans. The strategic importance of NFPs to forestry sector in Pan-European context is evident from the Oslo Ministerial Decision [37] from the sixth MCPFE held in Oslo in 2011, in which the developed and implemented NFPs in all European countries is the first goal of for- estry for the year 2020. The EU policy shared the same approach to the NFP as did the MCPFE in the pan-European context, as the EU Forest strategy [38] identified NFPs as a framework through which forest-related international commitments should be implemented. The same statement was made in the EU Forest action plan [39]. The Action plan also states that the development of NFPs should be done through application of the open method of coordination, which is a method based on voluntary actions of the member states of the European Union, and on its soft law (quasi-legal instruments which are not legally binding) mechanisms, such as criteria and indicators, benchmarking, best practices and broad participation.

\section{Participation and legitimacy in NFP process}

From the perspective of public administration, there are three rationales why public participation should be included in environmental decision making [21]; it enhances information basis and the scrutiny of environmental matters, it is a part in the well-established international human right legislation, and it constitutes a prerequisite for legitimacy, i.e. public acceptance of decision. Based on Aarhus convention [22] and other legislative acts, the same author gives a series of recommendations for participators decision making within a NFP process, which are presented in Table 1.

Since NFP process should cover wide range of topics through usage of participatory mechanisms, the issue of legitimization of the NFP process arises. This could be solved [23] by making the scope of the process restricted just to its participants, or making the process "Pareto efficient", i.e. to reallocate forest resources in such a way that at least one party is better off, without

\section{TABLE 1}

Recommendations for high participation in NFP process (based on [21])

\begin{tabular}{|c|c|c|}
\hline INITIATION PHASE & $\begin{array}{l}\text { PROCEDURAL ASPECTS OF } \\
\text { THE PROCESS }\end{array}$ & OUTCOME AND IMPLEMENTATION \\
\hline $\begin{array}{l}\text { Political commitment to implementation of the } \\
\text { decision }\end{array}$ & Early participation & $\begin{array}{l}\text { Participation in developing } \\
\text { the outcome }\end{array}$ \\
\hline Sufficient financial resources & $\begin{array}{l}\text { Genuine opportunity } \\
\text { to participate }\end{array}$ & Participation in implementation \\
\hline Cross-sectoral representation & Access to information & $\begin{array}{l}\text { Implementation has taken into } \\
\text { account outcome of participation }\end{array}$ \\
\hline $\begin{array}{c}\text { Independent } \\
\text { moderator / facilitator }\end{array}$ & $\begin{array}{l}\text { Standardized rules for } \\
\text { participation }\end{array}$ & $\begin{array}{c}\text { Legal review if implementation violates } \\
\text { decision }\end{array}$ \\
\hline $\begin{array}{l}\text { Agreement of sharing information and recogni- } \\
\text { tion of a long-term scope }\end{array}$ & Code of conduct & $\begin{array}{l}\text { Transparent implementation } \\
\text { and monitoring }\end{array}$ \\
\hline $\begin{array}{l}\text { Procedures for monitoring } \\
\text { and evaluation }\end{array}$ & & \\
\hline
\end{tabular}

1Type of document - formal NFP process; Process guided by NFP principles; similar process; none of the above, 
making anyone worse off. The practice has showed that this issue is usually resolved by broad stakeholder and public participation, which could have similar issues on its own. Participatory mechanisms exercised through NFP process may lack democratic legitimization, since stakeholders enrolled in it are "neither democratically authorized nor accountable to the population" [24]. One way of circumventing this problem would be opening up of the process to the public, but that would cause serious difficulties in the organization of the process, and would probably be met by a resistance of the representatives of stake-holding groups. Such unrestricted public access to the NFP process would also negate representatives, as it would allow some actors to expand their bargaining power simply by delegating additional participants. Learning from the NFP process in Germany, Elasser [24] argues that public acceptance of forest policy goals could by more improved by appropriately altering the partly incorrect public image of forestry, rather than with providing detailed information about specific goals and their background. Additional problem arise if unanimity is used, since the probability of reaching any decision decreases with the increase in the number of participants, thus perpetuating status quo. Pragmatic solution to these issues would be loosening the conditions of unanimity and unrestricted access when the progress in the NFP process is blocked. Other solutions to the veto situation would be [23]:

\section{- issue decomposition}

tracing the specific element of the issue that blocked the progress, and then removing it.

- issue linkage

linking the specific element with many other, making the entire package beneficial to all groups.

The same paper also states a series of procedural strategies for circumventing vetoes: concealing the issue behind vague or ambiguous wording; presiding from binding agreement to a more general notice of attention; putting the disagreement into brackets for later treatment and stating both views in the proposal of the document. These are just some of the procedural elements that the national leadership of the NFP process gives governments considerable discretion to change the relations among actors and ideas, thus affecting in a considerable way the policy outcome [25].

\section{Overview of NFP selected process}

The organization that is a global leader in endorsing the NFP on a global scale is the FAO and its NFP Facility. The Facility has been established in 2002 with the goal of supporting stakeholder involvement in the forest policy process. Majority of their activities are set in South America, Africa and Southeast Asia. Up to March 2012 they have implemented 749 activities in
70 partner countries, and 19 activities through 4 regional initiatives [40].

The issue on what NFP is has made it difficult to list which countries have it. One viable source for such list on the pan-European scale is the data base of reports on the pan-European Qualitative indicators for sustainable forest management and national implementation of commitments of the Ministerial Conference on the Protection of Forests in Europe, which belongs to the UNECE [41]. From this data base Table 2 was compiled, which provides some insight into the status of NFPs in Europe

Although the basis for this table are national reports of the respective ministries to the UNECE, the data presented in it should not be taken for granted, as the analysis of the documents referenced in the reports show that the criteria upon which they are characterized as a NFP or other types of documents is not clear. Examples issues are the categorizations forest Strategies as formal NFPs in Croatia and Macedonia [42], or German classification of their formal NFP [43] as being a similar to NFP.

Finland can be considered as a pioneer of formal NFP process [44]. Finnish NFP 2010 [45] was formulated in 1999 through broad public participation (38 experts, 59 public forums with 2900 participants that resulted in 190 written opinions), through strong cooperation with six other ministries and both private and public sector, and which was accompanied by formulation of 13 regional forest programs. The general orientation of this NFP is presented in the first sentence of the summary, as the documents covers "... forest utilization as seen from economic, ecological, social and cultural perspective". The same perspective is kept in the strategic aims of the program, as 7 out of 10 are primary economic. The document was revised in 2005 - 2008 period, when Finland's NFP 2015 was made [46]. The new program states the reasons for the revision: "... the impacts of global competition and Russian wood duties as well as climate and energy policy decisions of the EU". The funding needs of the new program also reflect these reasons, as now only minor role is played by the Ministry of Agriculture of Forestry. Accordingly, the general orientation has also changed, and it is now "... to increase welfare from diverse forests", and only half of the strategic aims are primary economic.

From all the NFP documents enlisted in the UNECE data base the Swiss NFP for the 2004-2015 period [47] has gone the farthest as regards to the operationalization of the strategic aims and in the scope of participation. Each objective has its indicator with 
TABLE 2

Status of implementation of NFPs in Europe

\begin{tabular}{|c|c|c|c|c|c|c|c|c|c|}
\hline Country & $\begin{array}{l}\text { Type of } \\
\text { docu- } \\
\text { ment }^{1}\end{array}$ & $\begin{array}{l}\text { Start of the } \\
\text { process / } \\
\text { year of the } \\
\text { most recent } \\
\text { document }\end{array}$ & $\begin{array}{l}\text { Inclu- } \\
\text { sion of } \\
\text { stake- } \\
\text { holders } \\
\text { (out } \\
\text { of } 10 \\
\text { groups) }\end{array}$ & $\begin{array}{l}\text { Uptake } \\
\text { of } \\
\text { MCPFE } \\
\text { instru- } \\
\text { ments } \\
\text { (out of } \\
6 \text { ) }\end{array}$ & Country & $\begin{array}{l}\text { Type of } \\
\text { docu- } \\
\text { ment }^{1}\end{array}$ & $\begin{array}{l}\text { Start } \\
\text { of the } \\
\text { process } \\
\text { / year of } \\
\text { the most } \\
\text { recent } \\
\text { document }\end{array}$ & $\begin{array}{l}\text { Inclusion } \\
\text { of stake- } \\
\text { holders } \\
\text { (out } \\
\text { of } 10 \\
\text { groups) }\end{array}$ & $\begin{array}{l}\text { Uptake of } \\
\text { MCPFE in- } \\
\text { struments } \\
\text { (out of 6) }\end{array}$ \\
\hline Albania & $\begin{array}{c}\text { guided } \\
\text { by }\end{array}$ & $1995 / 2005$ & 2 & 5 & Macedonia & formal & $2006 / 2006$ & 5 & 2 \\
\hline Austria & formal & $2003 / 2005$ & 10 & 6 & $\begin{array}{c}\text { Republic of } \\
\text { Moldova }\end{array}$ & similar & $2001 / 2001$ & 6 & 0 \\
\hline Belarus & $\begin{array}{c}\text { guided } \\
\text { by }\end{array}$ & $2007 / 2007$ & 2 & 1 & $\begin{array}{c}\text { Monte- } \\
\text { negro }\end{array}$ & guided by & $2006 / 2008$ & 6 & 1 \\
\hline Belgium & Similar & $2009 / 2011$ & 9 & 4 & Norway & guided by & $1998 / 2009$ & 6 & 2 \\
\hline Bulgaria & $\begin{array}{c}\text { guided } \\
\text { by }\end{array}$ & $2006 / 2006$ & 9 & 3 & Poland & similar & $1997 / 2005$ & 2 & 2 \\
\hline Croatia & formal & $2003 / 2003$ & 6 & 1 & Portugal & guided by & 1996/2006 & 6 & 1 \\
\hline Cyprus & formal & $2000 / 2002$ & 5 & 1 & Romania & similar & $2000 / 2005$ & 9 & 1 \\
\hline $\begin{array}{c}\text { Czech } \\
\text { Republic }\end{array}$ & formal & $2003 / 2008$ & 6 & 5 & \begin{tabular}{c|} 
Russian \\
Federation
\end{tabular} & - & $2007 / 2008$ & 5 & 1 \\
\hline Denmark & formal & $2001 / 2001$ & 9 & 1 & $\begin{array}{c}\text { Slovak } \\
\text { Republic }\end{array}$ & formal & $2006 / 2007$ & 4 & 4 \\
\hline Finland & formal & $1993 / 2008$ & 9 & 2 & Slovenia & formal & 1997/2007 & 9 & 3 \\
\hline France & formal & $2006 / 2006$ & 6 & 4 & Spain & similar & 1999/2008 & 6 & 5 \\
\hline Germany & Similar & $2008 / 2008$ & - & 0 & Sweden & similar & $2008 / 2008$ & 9 & 1 \\
\hline Hungary & formal & $2004 / 2007$ & 4 & 2 & Switzerland & formal & $2004 / 2004$ & 10 & 3 \\
\hline Italy & Similar & $2008 / 2009$ & 5 & 4 & Turkey & formal & $2004 / 2004$ & 1 & 3 \\
\hline Latvia & $\begin{array}{c}\text { guided } \\
\text { by }\end{array}$ & 1998/1998 & 7 & 3 & $\begin{array}{c}\text { United } \\
\text { Kingdom }\end{array}$ & similar & $2003 / 2003$ & 4 & 2 \\
\hline Lithuania & formal & $2002 / 2007$ & 6 & 2 & Ukraine & guided by & $2002 / 2010$ & 5 & 3 \\
\hline
\end{tabular}

1 Type of document - formal NFP process; Process guided by NFP principles; similar process; none of the above,

concrete target value, strategic direction, list of measures, implementing agency with list of partners and follow-up measures. The document was developed in 2002 and 2003 by six working groups comprising out of 130 experts, organized according to the PanEuropean Criteria and indicators for Sustainable Forest Management. There were also an NFP Forum with 28 decision makers, and a series of 35 seminars and workshops with 3400 participants. The result was an NFP document with balanced ecological, economical and social components.
Perhaps an unique example of a NFP process is the Kyrgyz one, in which a full logical sequence of policy documents and reforms has been made [48]. Entire process was performed with the assistance of the Kyrgyz-Swiss Forestry Support Program (1995-2009), by whose help the entire organizational structure of the sector has changed [49].

The formulation of strategic documents was done through the usage of a "mixed method" of decision making [50], by which the deductive instrumental 
("top-down") approach is combined the communicative ("bottom-up") approach. Practically this means the application of through negotiations between all interest groups in all steps of instrumental rationality (identification of problems, formulation of objectives, selection of means and implementation, monitoring and evaluation). Conceptually a sequence of policy reform can be represented by a "double spiral of power re-distribution" [50], in which the first outward spiral is characterized by a policy learning process, and is followed by an inward spiral characterized by policy negotiation.

The National Concept (i.e. a strategy) for Forestry Development was made in 1999, and since it comprised mostly out of short-term provisions, it was revised in 2004. National forest program was made the same year [52] which disseminated the 10 strategic lines in finer detail. The NFP explicitly specifies the need for Integrated Management Plans as a basic tool for its practical implementation at the sub-national level [48], and sets a clear division between control/ regulation responsibilities and economic function that should be privatized. The essence of the ten strategic lines was also kept in the National Action Plan (NAP) [53], which regulated the development of the sector in the period 2006-2010. Both NFP and NAP in Kyrgyzstan have clearly defined implementing agencies, expected results, indicators, resources and time frame.

The organizational changes that were introduced by the NAP led the sector to the increasing of authority of the central administration. However, the implementation of the NAP can be characterized as poor [49]. The strategic documents were not followed by a new law that would support it, and the same situation is with by-laws. In 2011, the state forest implementing agency had staff of 11 , and so the field-level forestry enterprises played a key role in the sector. These organizations had too poor funding to improve the status of forest, and very low salaries of its employees stimulated illegal logging [49]. In this case it seems that when the donor-driven "by-the-book type" reforms ended, the strategic determinants of the sector failed to cope with the day-to-day reality of a transition country.

A good example of different type of progression in formal NFP is Slovenia, who's first NFP [54] is in fact a strategy [55] with a strong ecological orientation. The Strategy was accompanied with an Operational Program of forest development 1996-2000, which only provided a financial framework for the goals set in the Strategy. Second NFP process started in 2005, and in 2007, with the help of five thematic workshops and 14 regional forums, Slovenian second NFP was made [56] The document is essentially a list of sectorspecific, ecologically oriented broad guidelines with indicators that have no threshold values, and with no financial frame of implementation. Although operational plan with concrete measures and responsible actors was set to supplement the NFP, until now such document was not made.

NFP process of Serbia can be characterized as a process of change. It began in 2003 with FAO's project "Institution development and capacity building for NFP of Serbia" and continued in 2005 with another FAO's project "Forest sector development in Serbia". The most important outcomes of the projects [57] were the Draft National Forest Policy, which was adopted in 2006 as a Strategy, and the fourth draft of the Law on Forests, which didn't came into power so far. At the same time the project of the Norwegian Forestry Group "Program for forest sector of Serbia" focused on more technical aspects of policy change, such as development of cost-effective forest management, development GIS capacities, national forest inventory and forest certification. All of those have strengthened and changed institutional environment of the forest sector in Serbia, and strive to a goal of National forest program in compliance to the procedural requirements of new modes of governance and adherence to the international forest-related commitments. So far such document has not been made.

The NFP process in the Federation of Bosnia is much more focused than in Serbia, in which the outline of the NFP document [58] has been made with balanced aims and list of thematic areas. Strong participation is present in many detailed sub-sectoral progress reports that have operational action plans with indicators, deadlines and implementing agencies; however so far there is no unifying text.

\section{Power relations and procedural design of NFP}

Power distribution among participants of the NFP process is an important factor contributing to the influence of stakeholders to the NFP process, and thus to the degree of realization of their interest in the outcome document. Most probably any NFP process will contain uneven distribution of representation of interests, due to the facts that specialized interest groups are more likely to be organized than general interests [59], and that costs and benefits of participation differ among interest groups [23]. One way of managing power misbalance would be designing the participatory and procedural aspects of NFP on a strong foundation in stakeholder analysis that makes the power relations overt; an example of which could be the work of International Institute for Environment and Development [60]. Another issue would be the 
principal-agent problem [61], by which the representatives of stakeholder groups may have little bargaining power, and that they may have their self-interest that diverge from the interests of their principals. This problem can be circumvented if the process is composed out of high-ranking representatives that have more discretionary power.

Goals within NFP process may be weakly defined, because powerful users of forests are opposed to further regulation through binding decisions, and so goal setting and inter-sectoral coordination within a NFP process may have just symbolic success in a form of a binding document that will not produce and substantial change. As such, the NFP document can be used by those leading the process as a tool by which they can raise public demand for their specific interests (as opposed to similar strategic documents from other sectors). Based on regional planning experiences from 11 Central European Countries, Krott [62] makes the following recommendations for the formulation of NFP:

- Focus on selected goals in which broad coordination of stakeholders can be achieved, in order to ensure at least some binding potential of the document.

- Make clear to forest users that the NFP process is a tool by which the sector will cope actively with demands and restrictions coming from its surrounding - this will diminish their rejection of additional regulation.

- Combine the NFP formulation with the modernization of the state forest enterprise - with clearly defining the multiple productions of forests (such as recreation, nature protection and non-wood forest products). With this strategy specific state budgets can be formulated, and NFP could help legitimize the demands of the state forest enterprise towards the public funds and the central government - and by doing so, NFP would gain a powerful supporter.

- Mediation - Use NFP as a mediator between all forest users, and so maintains its political influence. Mediation has its problems, since it requires social skills not common to foresters, and that certain interest groups and other parts of state administration might become aware of the power and increase in competence that the mediator role brings, and thus they might challenge it.

- Use NFP as an innovation tool for bringing about new products that are specific to forestry - examples of the stated may be creation of a market for the vast forest-related data contained within the information system of the state forest management company.
Not taking enough account of the power relations among stakeholders may even cause writing of an obituary to the NFP concept itself [60], as the Finnish NFP 2010 with its strong adherence to procedural justice produced symbolic NFP program dominated by neo-corporatist network of key forest policy stakeholders that pushed for enlargement of timber production subsidies $[63,64]$. In Germany the NFP process was used by the forestry coalition to stall at that time powerful nature conservation coalition in a long lasting negotiation process, with the goal of perpetuating the status quo. In Bulgaria the NFP process was understood by three different coalitions (state forestry, private forestry and the nature protection) as a tool to transform their policy core beliefs into public policy - and when it became obvious that this could not happen, the process was abandoned [10]. The examples described above show that usage of the deliberative mode of governance (and all of its principles that the scientific literature suggests) does not guarantee outcome justice in a NFP process, and that just as easily due to the determinants of power misbalance mean the consolidation of power of the major stakeholders.

The power relations among national stakeholders are not only determinant of the NFP process. The reliance on externally funded projects in the short run produces an NFP process characterized with strong procedural justice (as in Kyrgyz and Serbian case), but in the long run halts the process when the funding ends; as in Serbia it is unclear whether a document more substantive than the Strategy will be made, and the implementation of the strategic documents in Kyrgyzstan is under question.

The usage of NFP as a mechanism for implementation of international legislation is evident in all reviewed European examples. However the uptake of MCPFE instruments (most notably C\&I for SFM) is not pronounced. Although the C\&I for SFM are extensively used in the mostly technical reporting on forests $[65,66]$, from the data base of the UNECE of reports on the pan-European Qualitative indicators for SFM and national implementation of commitments of the MCPFE it is evident that they are not widely recognized as a platform upon which national forestry processes are built. This situation is currently being researched within the "Cl-SFM" (Implementing Criteria and Indicators for Sustainable Forest Management in Europe) project led by the EFICENT-OEF office of the European forest institute [67], The qualitative C\&I for SFM are recognized in the international forest policy domain, as they are one of the platforms for the negotiations on a legally binding agreement of forests in Europe. 


\section{Perspectives of NFP development in Croatia}

Strategic planning of the forestry sector is defined by the National Forest Policy and Strategy [68], which categorizes its activities into three time-categories: short-term (2003-2006), mid-term (2006-2008) and long-term (2008-). The activities are defined with respect to the strategic documents of the nature protection sector and international commitments, disseminated into the following topics: Management of forest ecosystems; Forest administration and legislation; Non-wood forest products; Forest based industry; Environment and physical planning; Education, research and international cooperation; Public relations. Assessment of the current situation transparently points to different issues, such as overlapping of different parts of state administration, restructuring of the Croatian Forests Ltd. (the state forest management company), management problems of private forests, under-managed non-wood forest products and the status of the wood-processing industry. However, unlike the realistic depiction of the status-quo, the strategic activities have been defined in an overambitious manner, and thus mostly have not been implemented. Although there is no explicit mention of NFP in the Strategy, it is defined as a principle instrument of the national forest policy in the Law on forests [69]. Croatia so far does not have an NFP. According to intermediary assessment of the Strategy [70]. $49 \%$ of the short-term activities and 33\% of mid-term and long-term activities have been implemented. Due to the changes that have had happened from the defining of the Strategy [71] and its partial implementation, there is a need for a process in which new goals for the forestry sector are to be set.

Within the conceptual framework of Advocacy Coalition Framework [72], the NFP process in Croatia would have to encompass conflicts between different core beliefs and/or policy core beliefs of different coalitions (namely coalitions of forestry and nature protection) that would be impervious to policy oriented learning. The reduction of conflict among coalitions by a national "policy broker" (mediators of policy process who channel information among stakeholders and directly influence the output, do not have strong policy beliefs or abandon their preferences; [73]) is also not a dominant strategy, since scientific and state administration organizations can also be seen as a parts of the advocacy coalitions. A possible strategy would be mediation through an international policy broker, which is a viable option - especially since the NFPs are a potential subsidy target of the EU [13]. The assistance of external donors could also facilitate the harmonization of the NFP with respective inter- national legislation both in its outcomes and in the process itself (i.e. usage of qualitative C\&I for SFM as a policy platform). However, overly relying on external factors may impede one of the basic principles of NFP - country leadership, and thus lower the implementation of NFP on symbolic level once the funding ends.

Another momentum that could influence the NFP process are the external perturbations that may weaken the cohesion of the forestry coalitions, as parts of it (such as representatives of private forests, parts of the scientific community and private consulting companies) may modify their policy beliefs in order to reduce the uncertainty caused by the possible reorganization of the state forest management company - Croatian Forests Ltd., or by the further diminishing of the "green tax" (OKFŠ). Another momentum may be the strengthening of the nature protection sector, notably the State institute on nature protection [74] which may through the upcoming implementation of the EU nature protection network - Natura 2000 may have significant impact on the NFP and the forestry sector in general. Further perturbations may come in raising the importance of economic viability of forests due to the general stagnating economic situation in Croatia, which would then ease the access of some members of the forestry coalition to the central government. The national economic situation together with the upcoming accession to EU may raise the importance of the elements outside of the policy subsystem to a level in which the power relations and conflicts [71] may not play the leading role (as in the case of second Finnish NFP).

As stipulated previously, making the conflicts overt and recognizing the power relations among stakeholders is a prerequisite for a NFP which is not just symbolically accepted; otherwise these factors will impede its implementation. And as the theory behind NFP suggest, we should step out the frame of classical, instrumental rationality (practical solution gained through participatory formulation and participation) onto the communicative rationality, in which there is a continuous exchange between stakeholders that leads to change and adaptation of institutional arrangements. In this light the lack of ratification or the implementation of NFPs may not be considered negatively, for it is the process itself that is most important, as is represents the true test of "failure" or "success". The time for evaluation of the current strategic forestry goals in Croatia has clearly come, and for its policy subsystem to enter an inward spiral of negotiations that would result in a formal NFP. And regardless on the specifics of the outcome document, such process is needed as it would bring about institutional arrangements fitting to the current situation. 


\section{REFERENCES}

1. UNCSD/IPF - UNITED NATIONS COMMISSION FOR SUSTAINABLE DEVELOPMENT / INTERGOVERNMENTAL PANEL ON FORESTS 1996 Report of the Secretary General. Ad Hoc Intergovernmental Panel on Forests. Third Session 9-20 September 1996 (E/CN, 17/IPF/1996/14)

2. SHANNON M A 1999 Moving from the limits and problems of rational planning toward a collaborative and participatory planning approach. EFI Proceedings 30, Vol I

3. SCHANZ H 2002 National forest programmes as discursive institutions. Forest Policy Econ 4: 269-279

4. FAO 2006a Understanding National Forest Programmes: Guidance for Practitioners. Rome, Italy. Available at: ftp://ftp.fao.org/docrep/fao/012/a0826e/a0826e00.pdf (Accessed: 3 February 2012)

5. MCPFE 2003a Vienna Resolution 1: Strengthen Synergies for Sustainable Forest Management in Europe through Cross-Sectoral Co-Operation and National Forest Programmes. Vienna, Austria. http://www.foresteurope.org/ filestore/foresteurope/Conferences/Vienna/vienna_resolution_v1.pdf (Accessed: 3 February 2012)

6. GLÜCK P, HUMPHREYS D 2002 Research into National Forest Programmes in a European context. Forest Policy Econ 4: 253-258

7. FAO 1996 Formulation, Execution and Revision of National Forestry Programmes-Basic principles and operational guidelines. FAO, Rome

8. FAO 2006b National Forest Programme Serbia Workshop on the National Forest Action Programme held at Head Office of the Public Enterprise "Srbija šume" in Belgrade on July 12 and 13, 2006

9. WINKEL G, SOTIROV M 2011 An obituary for national forest programmes? Analyzing and learning from the strategic use of "new modes of governance" in Germany and Bulgaria. Forest Policy Econ 13:143-154

10. FAO 1999 Status and Progress in the Implementation of National Forest Programmes-Outcome of an FAO World-wide Survey. FAO-Publication Series, Rome, p 42, Annexes

11. EGESTAD P S 1999 National forest programmes in clear terms. EFI Proceedings 30, Vol I

12. GLÜCK P 1997 European Forest Politics in Progress. In: Tikkanen I, Pajari B (eds) Future Forest Policies in Europe Balancing Economics and Ecological Demands. Proceedings of the International Conference, Joensuu, Finland, 15-18 June, 1997. EFI Proceedings no 22. European Forest Institute, Joensuu, Finland

13. BISANG K, ZIMMERMAN W 2003 Minimum requirements for sustainable use of forests in national forest programmes. Elements and principles for a study of Swiss forest policy

14. LINDBLOM C 1959 The science of muddling through. Public Administration Review 19: 79-88
15. HABERMAS J 1984 Theory of Communicative Action, Volume 1: Reasons and the Rationalization of Society. Beacon Press, p 460

16. RAWLS J 1999 A Theory of Justice. Harvard University press, p 560

17. DRYZEK J S 2000 Deliberative Democracy and Beyond. Liberals, Critics, Contestations. Oxford University Press, Oxford

18. ARTS B, VAN TATENHOVE J 2004 Policy and Power: A conceptual framework between the 'Old' and the 'New' Policy Idioms, 2004. Policy Sci 37: 339-356

19. ARTS B 2011 Forest Policy analysis and theory use: Overview and trends. Forest Policy Econ 16: 7-13

20. SHANNON M A 2002 Understanding Collaboration as Deliberative Communication, Organizational Form and Emergent Institution. EFI Proceedings 44: 7-27

21. APPELSTRAND M 2002 Participation and societal values: the challenge for lawmakers and policy practitioners. Forest Policy and Economics 4: 281-290

22. NECE 1998 The United Nations Economic Commission for Europe (ECE) Convention on Access to Information, Public Participation in Decision-Making and Access to Justice in Environmental Matters

23. ELASSER P 2002 Rules participation and negotiation and their possible influence on the content of a National Forest Programme. Forest Policy Econ 4: 291-300

24. ELASSER P 2007 Do "stakeholders" represent citizen interests? An empirical inquiry into assessments of policy aims in the National Forest Programme for Germany. Forest Policy Econ 9: 1018-1030

25. HOWLETT M 1999 Policy learning and policy change: reconciling knowledge and interests in the policy process. EFI Proceedings 30, Vol I

26. PÜLZL H, RAMESTEINER E 2004 A Methodological Tool for the Evaluation of the Implementation of International Commitments on National and Sub-National Levels. EFI Proceedings No. 52

27. IPF / IFF 2003 Proposals for Action. Available at: http:// www.un.org/esa/forests/pdf/ipf-iff-proposalsforaction.pdf (Accessed: 4 February 2012)

28. IFF 1999 Practitioner's Guide to the Implementation of the IPF Proposals for Action. Second Revised Edition, Eschborn, Germany

29. UNFF 2007 Non-legally Binding Instrument on All Types of Forest. Available at: http://www.un.org/esa/forests/ pdf/session_documents/unff7/UNFF7_NLBI_draft.pdf (Accessed: 4 Fēbruary 2012)

30. MCPFE 1993 Resolution H3: Forestry Cooperation with Countries with Economies in Transition. Helsinki, Finland. Available at: http://www.foresteurope.org/filestore/foresteurope/Conferences/Helsinki/helsinki_resolution_h3.pdf (Accessed: 4 February 2012) 
31. MCPFE 1998a Resoulution L2: Pan-European Criteria, Indicators and Operational Level Guidelines for Sustainable Forest Management. Lisbon, Portugal. Available at: http://www.foresteurope.org/filestore/foresteurope/ Conferences/Lisbon/lisbon_resolution_I2.pdf (Accessed: 4 February 2012)

32. MCPFE 1998b Annex 1 of the Resoution L2: Pan-European Criteria and Indicators for Sustainable Forest Management. Lisbon, Portugal. Available at: http://www.foresteurope.org/filestore/foresteurope/Conferences/Lisbon/ lisbon_resolution_12a1.pdf (Accessed: 4 February 2012)

33. MCPFE, 2002 Improved Pan-European Criteria and indicators for Sustainable Forest Management. Vienna, Austria. Available at: http://www.foresteurope.org/filestore/ foresteurope/Conferences/Vienna/Vienna_Improved_Indicators.pdf (Accessed: 4 February 2012)

34. MCPFE 2003b Vienna Living Forest Summit Declaration: European Forests - Common Benefits, Shared Responsibilities. Vienna, Austria. Available at: http://www.foresteurope.org/filestore/foresteurope/Conferences/Vienna/ vienna_declaration.pdf (Accessed: 4 February 2012)

35. MCPFE 2007a Warsaw Declaration. Warsaw, Poland. Available at: http://www.foresteurope.org/filestore/foresteurope/Conferences/Varsaw/warsaw_declaration.pdf (Accessed: 4 February 2012)

36. MCPFE 2007b Warsaw Resolution 2: Forests and Water. Warsaw, Poland. Available at: http://www.foresteurope. org/filestore/foresteurope/Conferences/Varsaw/warsaw_ resolution_2.pdf (Accessed: 4 February 2012)

37. MCPFE 2011 Oslo Ministerial Decision: European Forests 2020. Oslo, Norway. Available at: http://www.foresteurope.org/filestore/foresteurope/Conferences/Oslo_2011/ FORESTEUROPE_MinisterialConference_Oslo2011_EuropeanForests $20 \overline{2} 0$ AdoptedatMinConf14-16Junē2011. pdf (Accessed: 4 Fébruary 2012)

38. COUNCIL OF THE EUROPEAN UNION 1998 Council Resolution of 15 December 1998 on a Forestry Strategy for the European Union.1999/C 56/01. Available at: http:// eurlex.europa.eu/LexUriServ/LexUriServ.do?uri=OJ:C:199 9:056:0001:0004:EN:PDF (Accessed: 1 February 2012)

39. EUROPEAN COMMISSION 2006 Communication from the Commission to the Council and the European Parliament on an EU Forest Action Plan.Sec (2006) 748. Available at: http://eur-lex.europa.eu/LexUriServ/LexUriServ. do? uri=COM:2006:0302:FIN:EN:PDF (Accessed: 1 February 2012)

40. FAO 2012 National Forest Programme Facility. Available at: http://www.nfp-facility.org/en/ (Accessed: 3 March 2012)

41. UNECE 2012 Database of reports on the pan-European Qualitative indicators for sustainable forest management and national implementation of commitments of the Ministerial Conference on the Protection of Forests in Europe. Available at: http://www.unece.org/fileadmin/ DAM/publications/timber/ (Accessed: 8 February 2012)

42. GOVERNMENT OF THE REPUBLIC OF MACEDONIA 2006 Strategy for Sustainable Development of Forestry in the
Republic of Macedonia Available at: http://www.mnfpsfao.org.mk/ (Accessed: 15 February 2012)

43. BMWEL - DAS BUNDESMINISTERIUM FÜR ERNÄHRUNG, LANDWIRTSCHAFT UND VERBRAUCHERSCHUTZ, (FEDERAL MINISTRY OF FOOD, AGRICULTURE AND CONSUMER PROTECTION) 2003 NationalesWaldprogramm Deutschland (National forest program of Germany). BMVEL, Ref. 534. Available at: http://www.nwp-online. de/fileadmin/redaktion/dokumente/Phase-2/langfassung.pdf (Accessed: 15 February 2012)

44. OLLONQUIST P 2006 National Forest Program in Sustainable Forest Management. Working Papers of the Finnish Forest Research Institute 38: 14-27

45. FMAF - FINNISH MINISTRY OF AGRICULTURE AND FORESTRY, 1999 Finland's National Forest Programme 2010. Available at: http://wwwb.mmm.fi/kmo/ english/2010en.pdf (Accessed: 20 February 2012)

46. FMAF - FINNISH MINISTRY OF AGRICULTURE AND FORESTRY, 2008 Finland's National Forest Programme 2015. Available at: http://www.mmm.fi/attachments/ metsat/kmo/5yGFtgJQ5/Finlands_National_Forest_Programme_2015_final.pdf (Accessēd: 20 February 20̄12)

47. SAEFL - SWISS AGENCY FOR THE ENVIRNMENT, FORESTS AND LANDSCAPE 2004 Swiss National Forest Programme (Swiss NFP), Environmental documentation No. 363, Swiss Agency for the Environment, Forests and Landscape, Bern, p 117

48. KOUPLEVATSKAYA I 2006 The national forest programme as an element of forest policy reform: findings from Kyrgyzstan. FAO Corporate document repository. Available at: http://www.fao.org/docrep/009/a0970e/ a0970e05.htm 25.4.2012. (Accessed: 20 February 2012)

49. UNDELAND A 2011 Forest management and use in the Kyrgyz Republic: development potential. PROFOR, p 84

50. KOUPLEVATSKAYA-YUNUSOVA I, BUTTOUD G 2006 Assessment of an iterative process: The double spiral of redesigning participation. Forest Policy Econ 8: 529-541

51. GOVERNMENT OF THE KYRGYZ REPUBLIC 2004a Decree on approval of the concept of forestry development in Kyrgyz Republic. April 14, No. 256, Bishkek

52. GOVERNMENT OF THE KYRGYZ REPUBLIC 2004b Decree on approval of the National forest programme of the Kyrgyz Republic for the period from 2005 to 2015. November 25, No. 858, Bishkek

53. GOVERNMENT OF THE KYRGYZ REPUBLIC 2006 Decree on approval of the National action plan for the development of the Kyrgyz Republic from 2006 to 2010. September 27, No. 693, Bishkek

54. UNECE 2010 Reporting on the pan-European Qualitative Indicators for Sustainable Forest Management and National Implementation of Commitments of the Ministerial Conference on the Protection of Forests in Europe - Slovenian Country Report. Available at: http://www. unece.org/fileadmin/DAM/publications/timber/QL_SoEF_ Slovenia_2_final.pdf (Accessed: 20 February 2012) 
55. NARS - NATIONAL ASSEMBLY OF THE REPUBLIC OF SLOVENIA 1996 Program of Development of Forests in Slovenia (Program razvoja gozdov v Sloveniji).Official gazette of the Republic of Slovenia, 14.ISSN 1318-0576

56. NARS- NATIONAL ASSEMBLY OF THE REPUBLIC OF SLOVENIA 2007 Resolution on the National Forest Programme. Available at: http://www.mkgp.gov.si/fileadmin/mkgp. gov.si/pageuploads/GOZD/NFP_RS.pdf (Accessed: 20 February 2012)

57. VASILEVIĆ A, JOVIĆ P, JOVIĆ D, RADOSAVUEVIĆ A, TOMOVIĆ Z, FERLIN F, 2007 Šumarski sector Srbije i njegova politička, zakonodavna i organizacion areforma (Forest sector of Serbia and its political, legislative and organizational reform). Ministry of Agriculture, Trade, Forestry and Water Management of the Republic of Serbia, power point presentation

58. MAWF - MINISTRY OF AGRICULTURE, WATER MANAGEMENT AND FORESTRY, BOSNIA AND HERZEGOVINA, FEDERATION OF BOSNIA AND HERZEGOVINA 2008 Šumski program Federacije Bosne i Hercegovine; Plan, Program rada i Proračun (Forest programme of the Federation of Bosnia and Herzegovina; Plan, management program and budget). Available at: http://fmpvs.gov.ba/ texts/239_168_h.pdf (Accessed: 20 February 2012)

59. OLSON M 1971 The Logic of Collective Action.2nd edition. Harvard University Press, Cambridge

60. IIED 2005 Stakeholder Power Analysis. Available at: http://www.policy-powertools.org/Tools/Understanding/ docs/stakeholder_power_tool_english.pdf (Accessed: 20 February 2012)

61. REES S 1985 The Theory of Principal and Agent - Part I. $B$ Econ Res 37 (1): 3-26

62. KROTT M 1999 Political dynamics of regional forest planning - experiences of Central European Countries and Lessons for National Forest programmes EFI Proceedings 30 , Vol I

63. OLLONQUIST P 2002 Collaboration in the Forest Policy Arena in Finland - from Neo-Corporatist Planning to Participatory Program Preparation. EFI Proceedings No. 44
64. PRIMMER E, KYLÖNNEN S 2006 Goals for public participation implied by sustainable development, and the preparatory process of the Finnish National Forest Programme. Forest Policy Econ 8: 838-853

65. FOREST EUROPE, UNECE and FAO 2007: State of Europe's Forests 2007. Status and Trends in Sustainable Forest Management in Europe. 247 p

66. FOREST EUROPE, UNECE and FAO 2011: State of Europe's Forests 2011. Status and Trends in Sustainable Forest Management in Europe.

67. EFI 2012 Implementing Criteria and Indicators for Sustainable Forest Management in Europe - project site. Available at http://ci-sfm.org/ (Accessed: 7 October 2012)

68. GOVERNMENT OF THE REPUBLIC OF CROATIA 2003 Nacionalna šumarska politika i strategija (National Forest Policy and Strategy). Official Gazette 120/2003

69. CROATIAN PARLIAMENT 2005 Law on Forests. Official Gazette 140/05, 82/06, 129/08, 80/10, 124/10 and 25/12.

70. VULETIĆ D, IŠTOK I, PALADINIĆ E 2008 The National Forestry Policy and Strategy - Process or Static Document? 10th International Symposium on Legal Aspects of European Forest Sustainable Development, Sarajevo, Bosnia and Herzegovina, May 7-9.

71. MARTINIĆ I, POSAVEC S, ŠPORČIĆ M 2008 Time of intensive changes for Croatian forestry. 10th International Symposium on Legal Aspects of European Forest Sustainable Development, Sarajevo, Bosnia and Herzegovina, May 7-9.

72. SABATIER P A, JENKINS-SMITH H C (eds) 1993 Policy change and learning: an advocacy coalition approach. Westview Press, Boulder, p 290

73. SABATIER P A 1988 An Advocacy Coalition Framework of Policy Change and the Role of Policy-Oriented Learning Therein. Policy sciences 21 (2/3): 129-168.

74. WORLD BANK 2010 EU Natura 2000 Integration Project - NIP: Project Appraisal Document. Available at: http://www.min-kulture.hr/userdocsimages/ priroda/PAD\%20HR\%2028012011_za\%20web.pdf (Accessed: 7 October 2012) 